\title{
A modéstia e a ostentação no vestuário das mulheres alforriadas na Vila de Pitangui (1750-1820)
}

\author{
Modesty and ostentation in the clothing of the manumited women in the Pitangui village (1750- \\ 1820)
}

Ana Caroline Carvalho Miranda

https://orcid.org/0000-0002-2678-0135

Universidade Federal de Juiz de Fora

\begin{abstract}
Resumo: $O$ presente artigo tem como objetivo analisar de forma qualitativa o vestuário das mulheres alforriadas da vila de Pitangui, Capitania de Minas Gerais, Brasil, no período de 1750 a 1820. Através dos inventários post mortem, testamentárias e testamentos, verificamos o valor material e social dos trajes destas mulheres. Devido à representatividade e valor monetário de algumas peças deixadas, constituiu-se, em alguns casos, como herança no momento anterior à morte, doadas às outras forras, às filhas e comadres, como demonstração de afeto e gratidão. Através da investigação, notamos a valorização simbólica que as indumentárias carregavam, os valores culturais e o poderio socioeconômico de quem às vestia. Tratava-se de uma sociedade de Antigo Regime, onde as aparências tinham grande importância e atuavam como marcadores sociais. Desta forma, para as egressas do cativeiro, os trajes poderiam significar uma importante forma de afirmação da liberdade, distanciamento do passado escravista e, ainda, importante diferenciador entre cativos, libertos e livres.
\end{abstract}

Palavras-chave: Libertas. Vila de Pitangui. Vestuário. Sociedade.

\begin{abstract}
The present article aims to analyze in a qualitative way the clothing of the manumited women in the village of Pitangui, Captaincy of Minas Gerais, Brazil, from 1750 to 1820. Through the post mortem, wills and testament inventories, we verify the material and social value of these women's costumes. Due to the representativeness and monetary value of some pieces left, it was, in some cases, an inheritance before the death, donated to other lines, daughters and comadres, as a show of affection and gratitude. Through investigation, we noticed the symbolic valorization that the clothes carried, the cultural values and the socioeconomic power of those who wore them. It was an Ancien Régime, where appearances webe of great importance and acted as social markers.For those who were released from captivity, dress could mean an important way of affirming freedom, distancing themselves from the slavery past and, still, an important social differentiator between captives, manumited, and free people.
\end{abstract}

Keywords: Manumited women. Pitangui Village. Clothing. Society.

\section{Introdução}

O presente artigo analisa o vestuário das libertas da vila de Pitangui, Capitania de Minas Gerais, no período de 1750 a 1820. Para tanto, utilizamos 20 inventários post mortem, 12 testamentos e 2 testamentárias deixados pelas mulheres, no intuito de localizar o valor material e simbólico dos trajes. ${ }^{1}$ Por se tratar de um segmento social específico, como demonstra o nosso

Esta obra está licenciada sob uma Creative Commons - Atribuição 4.0 Internacional

\footnotetext{
${ }^{1}$ Para o período analisado, encontramos no Arquivo de Pitangui cerca de 401 inventários post mortem de mulheres, e dentro deste número, localizamos 20 inventários relativos às forras, o que representa $5 \%$ do total. No que se refere aos testamentos, o total de documentos relativos às mulheres em geral é de 89 fontes e dentro deles há 12 pertencentes às forras, o que representa $13 \%$ do montante. Não há como dimensionar de forma precisa o total das fontes existentes para o recorte temporal, devido ao estado em que o arquivo se encontra há um bom tempo: sem organização, serialização e higienização de grande parte dos manuscritos, o que impossibilita a disponibilidade para a consulta.
} 
objeto de estudo, a forma de vestir poderia significar o afastamento do passado escravista, uma forma de diferenciar-se dos cativos e demonstrar certo poderio social e econômico.

A seleção do recorte temporal foi estabelecida em virtude do período concentrar o maior número de documentos de libertas para o século XVIII, e se estende até o fim do XIX, no fim do período colonial. A escolha da região se justifica pela importância da vila de Pitangui como grande produtora agropastoril, abastecendo não apenas a Capitania de Minas Gerais, mas também outras regiões da América Portuguesa, como o Rio de Janeiro (SILVA, 2008, p. 232-237). Ademais, há poucos trabalhos que se concentram na localidade e em sua população alforriada de forma específica.

O vestuário, tema escolhido, era tido como um dos principais símbolos de distinção social, ocupando lugar de destaque na sociedade das Minas setecentistas. Algumas escravas e forras ostentaram nas vilas e nas áreas rurais utilizando tecidos nobres, joias e adereços, diversos deles importados. No continente africano, os adornos faziam parte tanto do cotidiano masculino quanto do feminino e possuíam significados variados: o segmento social pertencente, a situação econômica, a idade e a matriz familiar daqueles que os usavam (PRIMO, 2008, p. 4).

$\mathrm{Na}$ América Portuguesa, distinguir-se por meio dos trajes gerou vários conflitos e leis que tentavam restringir às negras o uso de determinadas vestimentas, como assegura Cláudia Cristina Mól (2004, p. 178). Tratava-se de uma sociedade de Antigo Regime, onde as aparências tinham grande importância. Para os indivíduos que saíam do cativeiro, havia a necessidade de afirmação do status de liberto. Uma das formas dessa afirmação era através da aquisição de símbolos de dignificação: cativos, moradas, animais, ouro, vestuário e família. Nesse sentido, os alforriados objetivavam deixar de ser vistos como estranhos para a sociedade - como eram na condição de escravos - ou seja, excluídos, e tornar-se incluídos, parte do corpo social, agora não apenas com deveres, mas também com direitos (SOARES, 2011, p. 36). Nesse sentido, o prestígio social do liberto estava ligado à forma como se portava, ao trabalho que desempenhava e aos laços com pessoas influentes, ou seja, estava atrelado às redes sociais estabelecidas antes e após o cativeiro (GUEDES, 2011).

Dentro disso, o vestuário atuava como parte do cenário urbano e rural, uma vez que funcionava como importante demarcador das diferenças entre os segmentos sociais. Evidenciava a hierarquia entre os indivíduos e mostrava quem detinha maior poder. Para analisar qualitativamente os dados referentes à nossa pesquisa, compomos um banco de dados com as seguintes informações sobre as libertas: nome, ano, item do vestuário, joia, adorno e valor do objeto. Através disso, comparamos a qualidade e o preço dos itens listados por elas nos inventários, testamentárias e testamentos. Como resultado, encontramos, de modo geral, um vestuário diversificado, de diferentes valores, tecidos e qualidades. Os bens mais caros possuíam detalhes em renda, pelicas, sedas, ouro e prata. Já os de preços menores eram feitos de baeta, tecidos mais grosseiros e joias em latão e outros metais menos nobres.

Houve ambas as influências nos trajes das libertas: a europeia e a africana. A primeira pôde ser notada por meio dos tecidos importados, lenços e sapatos; a segunda através dos fios de contas, corais e da combinação de saias e camisas coloridas, tradição que parte das mulheres africanas usavam (MÓL, 2002). Dentro disso, sugerimos que haviam roupas para serem usadas no cotidiano, em casa e no trabalho, e outras para ocasiões especiais, como em festividades e cerimônias religiosas.

Ademais, as libertas buscavam aparentar-se da melhor forma possível para a sociedade, mostrando que já não mais pertenciam ao grupo dos escravos e à desonra, própria do cativeiro (PATTERSON, 2008, p. 34-35). Para parte das libertas faltava o básico dentro dos lares, como objetos de cozinha e móveis, mas não deixavam de possuir vestes e adornos para ostentar nas vilas, o que denota a extensa preocupação com as aparências e com a forma com que se portavam em público. Na medida em que construíam o patrimônio material e suas redes de relacionamento, 
produziam, igualmente, o patrimônio imaterial, ou seja, a honra, a liberdade e a dignidade. E, dentro disso, parte também dessas mulheres ascenderam economicamente e reafirmaram o status social alcançado por meio das indumentárias.

Para melhor assimilarmos o comportamento deste segmento em sociedade, dialogamos com as perspectivas da História Social. Tais perspectivas prezam pelos modos de constituição e ação dos atores sociais, do coletivo e das relações que configuravam historicamente as estruturas sociais e econômicas. Reiteram a dinâmica histórica da estratificação social, bem como as identidades e relações socioeconômicas construídas pelos sujeitos (CASTRO, 1997, p. 80).

\section{Os trajes como parte do teatro social}

O uso das roupas e adornos refletia o funcionamento dos mecanismos sociais, culturais e econômicos, transparecia as normas do comportamento religioso e moral dos indivíduos. Segundo Daniel Roche, as leis que eram voltadas para a compra e posse das vestimentas revelam as ligações entre a cultura material, religiosa, filosófica e jurídica, esta última dizia respeito às restrições colocadas pelas leis suntuárias (ROCHE, 2007).

As leis suntuárias visavam delimitar os usos e costumes. Em várias sociedades, tanto na antiguidade quanto no medievo e na modernidade, existiram regras que incidiam diretamente sobre o vestuário, alimentação e composição das casas. Além disso, estas leis tinham como propósito regulamentar a balança comercial, limitando o comércio dos produtos importados e exportados (LIPOVETSKY, 1989, p. 41).

Os inventários post mortem e testamentos nos proporcionam a percepção e o significado que cada peça do vestuário tinha no período colonial. Tais fontes nos permitem visualizar a forma de trajar de cada segmento social, assim como a circulação e o valor dos tecidos e adornos. Em relação à América Portuguesa e Europa, existiam legislações que visavam delimitar o uso das indumentárias pelos moradores, quais grupos sociais poderiam utilizar determinadas peças, acessórios e armas.

Segundo Silvia Hunold Lara, as legislações que diziam respeito às indumentárias permitidas a diversas categorias sociais são bastante antigas. Em Portugal, as primeiras determinações reais a restringir o tipo, a qualidade e os materiais para as vestimentas e armas são datados para a segunda metade do século XV (LARA, 2007, p. 87-88). Elas visavam controlar os excessos, garantir que a boa ordem permanecesse vigente e tornar sempre visível as distinções sociais. ${ }^{2}$ Tais leis foram incorporadas às Ordenações Manuelinas e depois às Filipinas.

Em 1677, a Coroa Portuguesa produziu determinadas cláusulas que condenavam a ostentação e os gastos imoderados dos vassalos em relação às roupas, com a justificativa de que isso os empobrecia e envaidecia, causando a ruína das famílias nobres e facultosas (LARA, 2007, p. 88). Nestas cláusulas, proibia-se que qualquer indivíduo portasse enfeites, botões, fitas, fivelas, ou qualquer outro adorno que fosse de prata e ouro, e também delimitava que ninguém utilizasse capas ou carapuças que impedissem de deixar o rosto a mostra. A maior parte das restrições feitas pelo rei girava em torno de evitar que as pessoas comuns chegassem a adquirir bens e roupas parecidas com as que os nobres usavam.

Em 1749, foram propostas outras leis que interferiam na circulação de pessoas com determinadas peças de roupa. Nelas, haviam regras direcionadas aos negros e mulatos, proibindoIhes a circulação com alguns tecidos, com multa em dinheiro ou açoites. O intuito era fazer com que eles, mesmos os livres e libertos, não se vestissem luxuosamente como forma de evitar o mau exemplo para os demais negros e para nunca se equipararem ao vestuário dos brancos (MAGALHÃES, 1997).

\footnotetext{
${ }^{2}$ A boa ordem aqui é entendida como moral, mantenedora dos princípios cristãos, baseada na afirmação das diferenças entre os indivíduos e no respeito a cada categoria social.
} 
Íris Kantor, através de seu trabalho sobre as indumentárias e seus significados em Minas Gerais no século XVIII, pode verificar como a defesa da nobreza, da honra e da moral foram baseadas nos critérios de cor. Nesse sentido, ressalta que os trajes marcavam as distâncias sociais e diferenciavam os costumes dos indivíduos que ali viveram. Um exemplo disso foi o controle sobre o uso de rendas, bordados, pedras preciosas, ouro e prata por parte da população negra (KANTOR, 1995, p. 121-122). No entanto, parte do segmento de pretos e crioulos forros não deixou de circular nas vilas setecentistas com roupas requintadas, joias e adereços de valor (MAGALHÃES, 1997, p. 82-199).

Carla Maria de Carvalho Almeida ressalta que os habitantes da comarca de Vila Rica investiram parte de seus rendimentos em objetos que garantiam o "bom tratamento, ou seja, em roupas, adornos, joias e sapatos". Isto refletia o ideal aristocrático e de corte presentes na localidade em razão de ser a sede da capitania e pelo trânsito contínuo de pessoas. Na região, moravam autoridades administrativas, eclesiásticas e homens letrados. Segundo a autora:

Naturalmente, os ocupantes de tais cargos tendiam a ser pessoas mais qualificadas e, portanto, mais habituadas ao 'bom tratamento'. Assim, é muito provável que os hábitos destes 'homens bons' fossem difundidos entre a população em geral e se tornassem uma forma de vida a ser imitada por aqueles que pretendessem a eles se igualar (ALMEIDA, 2001, p. 76).

À vista disso, as populações livre e liberta tentavam seguir os passos das elites quando transitavam nos espaços públicos. A preocupação demasiada com as aparências e com a exteriorização da riqueza denotava o interesse pelo bom tratamento e pela boa reputação. Entretanto, poderia disfarçar a dura realidade do cotidiano nos ambientes domésticos: a pobreza traduzida pelo pouco mobiliário, a falta de itens básicos para a cozinha, para dormir e a utilização de trajes simples, sem nenhum conforto.

Diante destes ideais propostos pelos segmentos sociais mais elevados, havia vestimentas destinadas ao âmbito privado do lar e outras específicas para o meio público, festas, ritos fúnebres, missas. Por exemplo, era permitido às mulheres andarem com "mangas de camisa" apenas em casa, jamais fora (MÓL, 2002). Em relação às mulheres de cor, mesmo havendo restrições, não eram suficientes para impedir que elas se vestissem como bem quisessem. $O$ pintor e desenhista Jean Baptiste Debret deixou suas impressões sobre a forma com que as mulheres negras se apresentavam nas ruas do Rio de Janeiro no século XIX. Abaixo, duas de suas pinturas.

Figura 1: Chica da Silva e seu séquito

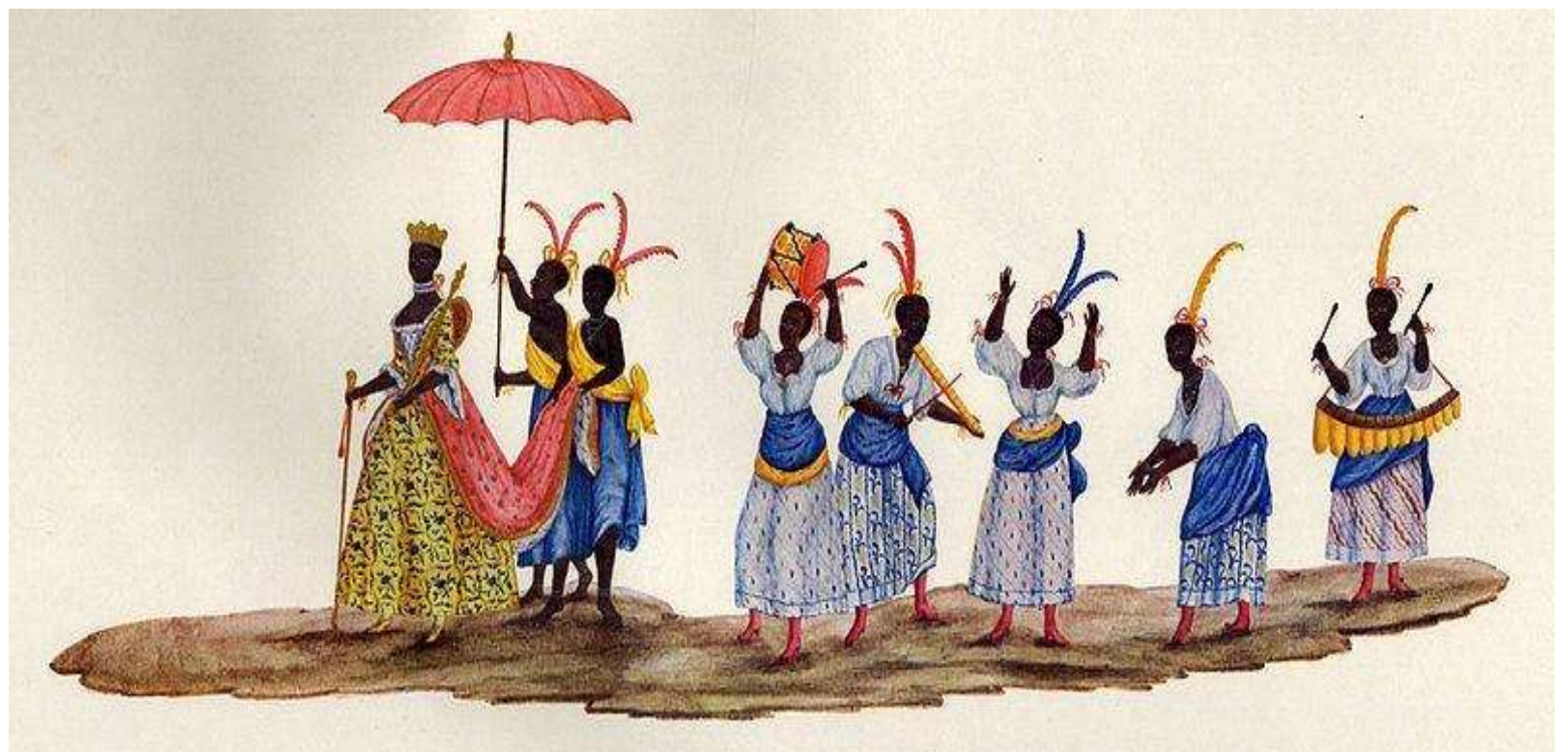

Fonte: DEBRET, 1978. Viagem pitoresca e histórica ao Brasil. Litogravura do tomo III. 
Figura 2: Negra tatuada vendendo caju - século XIX.

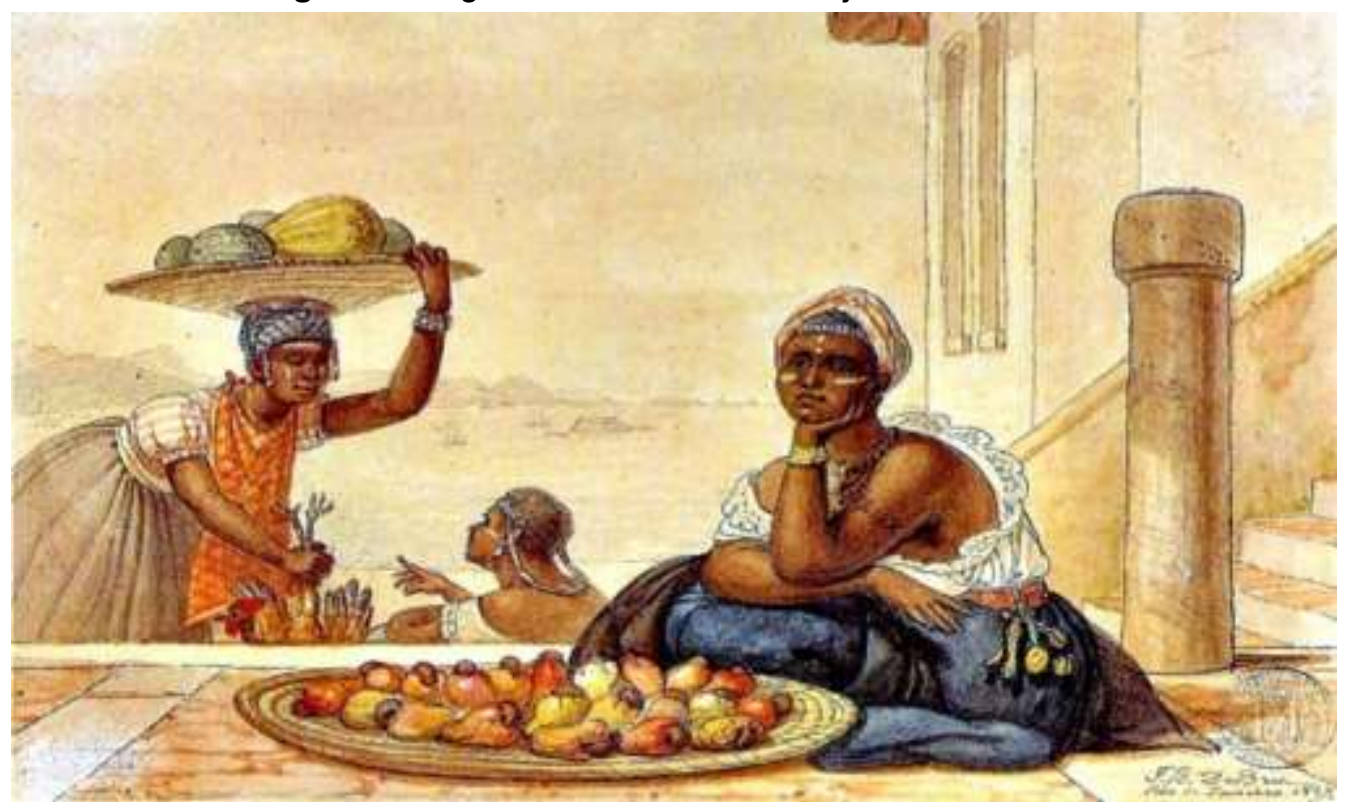

Fonte: DEBRET, 1978. Viagem pitoresca e histórica ao Brasil. Litogravura do tomo III.

$\mathrm{Na}$ segunda imagem, percebemos as vestimentas das negras trabalhando: trajando blusas, saias longas, panos na cabeça e adornos que remetem a cultura africana, como balangandãs, colares com muitas voltas, pulseiras e figas. Os adereços usados na cintura geralmente eram usados para atrair "bons fluídos", prevenir dos perigos e servir de amuletos (LARA, 2007, p. 119120). Durante a época moderna e, sobretudo nos séculos XVII e XVIII, os panos importados da Ásia, Índia e Europa atendiam a demanda africana e constituíram-se como valiosas mercadorias de troca no tráfico negreiro (THORNTON, 2004, p. 49-52). Ademais, observa-se que a negra vendedora de caju aparece com tatuagens e pinturas faciais, outra referência a cultura africana, pois determinados grupos étnicos pintavam seus corpos para distinguir-se dos demais (MÓL, 2002, p. 77-78).

Apesar das mulheres serem retratadas na segunda imagem com roupas simples, não significa que todas as negras se apresentavam em público da mesma forma. Parcela delas utilizou um vestuário pomposo composto de tecidos finos e joias valiosas para trabalhar, ir à missa, casamentos e comemorações populares. Algumas, como é mostrado na primeira imagem, vestiamse demasiadamente ostentosas, com saias de tecidos finos, brincos de ouro, colar de fios de conta, sapatos e chapéus. Além disso, algumas andavam pelas ruas das vilas acompanhadas de um séquito de escravos, como foi o caso de Chica da Silva e de outras libertas (MIRANDA, 2017, p. 110).

O trânsito feminino negro gerou desconforto as demais pessoas da sociedade. Um exemplo disso foi o caso do bispo do Rio de Janeiro, que no início do século XVIII enviou uma carta ao rei denunciando as pretas, pardas e outras mulheres de cor por andarem pelas ruas da cidade vestidas de sedas, garças e ouro (LARA, 2007, p. 120-121). O que não garantiu que elas parassem de se portar desta maneira. As escravas e libertas circulavam por todos os lugares das vilas e arraiais: vendendo secos e molhados em suas lojas fixas, no entorno das minas, nas cerimônias religiosas, nas reuniões e festas das irmandades leigas, em contato com pessoas de diferentes segmentos sociais (FIGUEIREDO, 1999).

Beatriz Magalhães verificou que em Vila Rica, no século XVIII, parcela dos manumitidos possuiu roupas requintadas e portou joias de alto valor, igualando-se às roupas de indivíduos de segmentos sociais elevados (MAGALHÃES, 1997). O que corrobora com a premissa de que os indivíduos, após se libertarem, tinham a necessidade de aproximar dos livres e acumular riquezas, 
preocupados, desta forma, com a exteriorização. Além disso, o vestuário da população egressa do cativeiro significava também a distinção entre os demais negros que estavam na condição de escravos.

Sustentado pela teoria de Orlando Patterson, Márcio Soares afirma que o escravo representava socialmente um ser desprovido de direitos e submisso às vontades de seu proprietário, visto como desenraizado e ligado aos ofícios mecânicos. A partir do momento em que Ihe era concedida a liberdade, este começava a viver, já não era mais submisso, passava a ter direitos e lutava por sua honra (SOARES, 2001, p. 41). Nesse sentido, o vestuário fazia parte dos importantes símbolos de reputação e dignificação social para àqueles que saíam do cativeiro. Um exemplo disso era através da utilização de sapatos, negada aos cativos e permitida para os livres e manumitidos. Ademais, o preço dos calçados era alto, fator que determinava o público que os usavam (MAGALHÃES, 1997, p. 7).

\section{O vestuário das libertas da Vila de Pitangui}

As mulheres forras da vila de Pitangui fizeram parte do cenário urbano, rural e das áreas mineradoras, atuando como costureiras, vendeiras, lavadeiras, donas de lojas, vendedoras ambulantes, mineradoras e lavradoras. Através de seus ofícios, conquistaram os seus bens de valor, móveis e imóveis. Parte delas viveu de forma modesta, com poucos itens nas casas, móveis escassos e raras vestes. Outra parte angariou pecúlio, adquiriu casas, escravos, móveis, vestuários luxuosos, adornos e joias, demonstrados através de seus testamentos, testamentárias e inventários post mortem.

No que tange especificamente aos trajes destas mulheres, percebemos a presença de variada gama de tecidos, camisas, capas, coletes, lenços, meias, saias e panos por elas utilizados. Variaram entre tecidos finos e simples. Os finos eram de seda, lemiste, bretanha, pelica, gala, crepe, cetim e veludo, com detalhes em rendas e bordados; os simples eram de baeta, algodão, camurça, melânia e linho. A baeta e a melânia eram tecidos feitos a partir da lã grossa, e a camurça era de origem animal (PEREIRA, 2004, p. 139-151).

Segundo o glossário de termos têxteis e afins, composto por Manuela Pinto da Costa, a seda é um tecido produzido a partir do casulo do bicho-da-seda, e os panos que eram produzidos com esta fibra possuíam várias designações, dentre elas, o tecido denominado seda (COSTA, 2004, p. 157). O lemiste, pano de lã muito fino de origem inglesa, era vendido apenas na cor preta e geralmente tinha por finalidade representar o luto, assim como o fumo (COSTA, 2004, p. 59). A pelica era um tecido composto de pele fina, curtida, utilizado para fazer luvas (COSTA, 2004, $p$. 154). O crepe era feito de seda mais ou menos baço, de fio de seda em qualquer cor, leve, próprio para confecções femininas, conhecido como crepe da China ou crepe cetim. Poderia, igualmente, ser preto e usado em sinal de luto (COSTA, 2004, p. 143). O cetim era uma espécie de pano de seda, lustroso e fino (COSTA, 2004, p. 216). A bretanha era um pano nobre de algodão que era tecido pelos cafres (PEREIRA, 2008, p. 58). E o veludo era liso de um lado e felpudo de outro, podia ser de lã, algodão ou de seda. Possuía diversas designações e poderia ser bordado, cinzelado, frisado, entre outros (PEREIRA, 2008, p.160).

O preço, a quantidade e as cores dos itens descritos na documentação foram variados. Dependiam do estado de conservação do material e do tempo de uso. No inventário de Mariana Gomes de Araújo, preta forra, feito no ano de 1775, constavam os seguintes itens:

Dois côvados de lemiste preto em bom uso visto e avaliado na quantia de $6 \$ 000$ réis Um leque fino novo visto e avaliado na quantia de $2 \$ 400$ réis Um de Braga já usado visto e avaliado na quantia de $\$ 900$ réis Um par de sapatos de veludo carmesim com suas ponturas de prata já usados vistos e avaliados na quantia de $1 \$ 200$ réis Um par de chinelos de reto carmesim visto e avaliado na quantia de $\$ 720$ réis 
Dois vasos de fita carmesim vistos e avaliados na quantia de $\$ 300$ réis

Uma terça de fita carmesim vista e avaliada na quantia de $\$ 180$ réis

Uma da llha de Bretanha usada com renda vista e avaliada na quantia de $\$ 600$ réis

Uma camisa da Bretanha com babados de renda vista e avaliada na quantia de $2 \$ 400$ réis

Um cabeção de camisa de Bretanha com babados de cambraia e seus bordados visto e avaliado na quantia de $2 \$ 400$ réis

Uma camisa de linho vista e avaliada na quantia de $\$ 600$ réis

Um colete de veludo usado com seu cordão visto e avaliado na quantia de $2 \$ 400$ réis

Um par de meias de algodão de renda bem usado visto e avaliado na quantia de $\$ 150$ réis

Um lenço de seda visto e avaliado na quantia de $\$ 600$ réis

Um lenço de seda visto e avaliado na quantia de $\$ 450$ réis

Um terceiro de algodão visto e avaliado na quantia de $\$ 225$ réis

Um enxergão de linhagem já velho visto e avaliado na quantia de $\$ 600$ réis

Uma timão de baeta visto e avaliado na quantia de $3 \$ 600$ réis

Uma saia de baeta preta bem usada vista e avaliada na quantia

de $\$ 600$ réis

Uma dita de baeta azul em bom uso vista e avaliada na quantia

de $3 \$ 600$ réis

Uma dita de brilhantes com barra de baeta cor de rosa vista e

avaliada em $6 \$ 000$ réis. $^{3}$

A soma dos itens do vestuário de Mariana totalizava $35 \$ 955$ réis, valor relativamente alto se comparado aos mesmos itens deixados pelas demais mulheres pertencentes ao mesmo segmento social de Pitangui. Importante atentarmos para os detalhes nos itens elencados por ela, como a qualidade dos tecidos: alguns nobres como o Lemiste, as camisas da Bretanha; o colete de veludo; o lenço de seda, a saia de brilhantes; dois leques finos e por último os sapatos, um dos maiores símbolos que dividia a população livre e liberta da cativa, visto que apenas aqueles da última condição que não poderiam usar. As cores dos tecidos também foram variadas: preta, azul, carmesim e detalhes em rosa. Carmesim era uma das denominações para o vermelho, muito utilizado pelos africanos (MÓL, 2002, p. 180).

Maurícia Gonçalves, preta forra natural da Costa da Mina e detentora do maior plantel de escravos entre as libertas, também utilizou de roupas e adornos luxuosos para se apresentar na sociedade da vila de Pitangui no século XVIII. Em seu inventário de bens constavam:

\footnotetext{
Uma saia de veludo preto em bom estado avaliada em $14 \$ 400$ réis

Um colete de veludo preto avaliado em $\$ 900$ réis

Uma capa de veludo avaliada em $1 \$ 800$ réis

Uma calça de cetim bordada de retrós forrada de nobreza azul avaliada em $12 \$ 000$ réis

Um cordão de ouro fino que pesa 04 oitavas 03 quartos avaliado em $6 \$ 737$

Um par de brincos de ouro e laços compridos de diamantes olhos de mosquitos que todos pesam quatro oitavas e meia e um vintém avaliado em $8 \$ 000$ réis

Um laço branco comprido com camadas que pesam 04 oitavas, três quartos e quatro vinténs avaliado em $6 \$ 000 .{ }^{4}$
}

O guarda-roupas de Maurícia não se destaca pelo número de itens declarados, pois, como podemos perceber, não é grande, mas pela qualidade e valor dos artigos. Ela possuiu roupas de veludo, cetim, joias finas e valiosas com ouro e diamantes. A soma das oito peças totalizou $48 \$ 837$ réis.

Os itens mais utilizados pelas libertas da localidade foram saias, camisas, lenços e joias. $\mathrm{Na}$ documentação total encontramos 22 joias, 21 saias, 12 camisas e nove lenços. Segundo os viajantes que passaram pelas Minas Gerais no século XIX, era comum que as alforriadas se vestissem com camisas e saias (MÓL, 2002, p. 180-182). Elas citaram também artigos como

\footnotetext{
${ }^{3}$ IHP, Fundo CMP, Seção Justiça, Inventário de Mariana Gomes de Araújo - preta forra. 1775. Cx 015 Dc 004.

${ }^{4}$ IHP, Fundo CMP, Seção Justiça, Inventário de Maurícia Gonçalves - preta forra. 1798. CX 032/007.
} 
cabeção e timão. Cabeção era a parte que ficava em torno do pescoço, virada para trás ${ }^{5}$. Timão era uma camisola comprida ou casaco grosseiro usado por escravos, mulheres de baixa condição e crianças, como abrigo do frio (PEREIRA, 2004, p. 68). Abaixo a descrição e quantificação de todos os itens declarados pelas forras.

Quadro 01: Itens relacionados ao vestuário listados nos inventários e testamentos das libertas da vila de Pitangui (1750-1820)

\begin{tabular}{|l|l|}
\hline \multicolumn{1}{|c|}{ Item } & Quantidade \\
\hline Brincos de ouro/aljôfares/prata/laços com diamante & 10 \\
\hline Botons & 02 \\
\hline Cabeção linho/camurça/bretanha/babados & 05 \\
\hline Calça de cetim com nobreza azul & 01 \\
\hline Camisas de bretanha/renda/babados/linho & 12 \\
\hline Capa de baeta/veludo & 03 \\
\hline Chinelos de rife carmesim & 01 \\
\hline Colete de veludo preto//verde com cordão & 02 \\
\hline Cordão de ouro fino & 01 \\
\hline Fios de conta de ouro de pescoço/prado/prata/contas & 03 \\
\hline Fivela de estanho/prata & 02 \\
\hline Laço com brinco de ouro/pedras engemadas com & \\
brincos/camadas & 04 \\
\hline Lenços de algodão/seda/linho/velantão francês/ & 09 \\
\hline Meias de algodão/renda/linho & 03 \\
\hline Saias de baeta & 01 \\
\hline Saias de baeta preta & 02 \\
\hline Saias de baeta azul & 02 \\
\hline Saias de baeta anil & 01 \\
\hline Saia de baeta cor do mar & 01 \\
\hline Saias de algodão & 02 \\
\hline Saia de camelão & 01 \\
\hline Saias da Bretanha & 02 \\
\hline Saia de tecido fino & 01 \\
\hline Saia de pano alvadio grosso & 01 \\
\hline Saia de estepe & 01 \\
\hline Saia de melânia & 01 \\
\hline Saia de brilhantes com barra de baeta cor de rosa & 01 \\
\hline Saia de gala preta & 02 \\
\hline Saia de veludo preto & 01 \\
\hline Saia de salamanca & 01 \\
\hline Sapato de veludo carmesim com ponturas de prata & 01 \\
\hline Sapato de pelica & 01 \\
\hline Total & $\mathbf{8 2}$ \\
\hline
\end{tabular}

Fonte: IHP, Fundo CMP, Seção Justiça, Inventários.

Como demonstra o quadro acima, nos trajes das libertas de Pitangui continham desde tecidos comuns e de baixo valor como o linho, algodão e baeta, até os mais finos como a sede, lemiste, veludo, gala e nobreza. As joias também chamam atenção, a maioria em ouro e algumas com aljôfares e fios de conta. Os aljôfares, corais, fios de conta e demais pérolas miúdas eram muito utilizados pelas mulheres de cor na América Portuguesa. Os corais eram usados no continente africano desde o século $X V$ e os portugueses eram os principais fornecedores e comerciantes, segundo Eduardo França Paiva. De acordo com o mesmo autor, era comum o uso destes adereços por parte das libertas na capitania de Minas Gerais, assim como o uso de balangandãs, figas e outros adornos vinculados à cultura africana (PAIVA, 2001, p. 221-233).

\footnotetext{
${ }^{5}$ SILVA, Antonio Moraes. Diccionario da lingua portugueza - recompilado dos vocabularios impressos ate agora, e nesta segunda edição novamente emendado e muito acrescentado, por ANTONIO DE MORAES SILVA. Lisboa: Typographia Lacerdina, 1813, p. 211.
} 
Além dos itens acima arrolados, algumas mulheres da vila de Pitangui declararam possuir côvados e libras de tecido, medidas utilizadas no período colonial brasileiro. O côvado era uma das medidas de comprimento de tecidos, equivalente a três palmos ou 0,66 cm, e a libra era medida de peso, equivalente a 0,459 kg (CARRARA, 2001, p. 73). Mariana Gomes de Araújo foi a liberta que mais possuiu medidas de tecido, contendo em seu inventário:

Dois côvados de pano lemiste avaliados em $6 \$ 000$ réis

Um côvado de crepe fino avaliado em $2 \$ 400$ réis

Um côvado de pano de Braga avaliado em $\$ 900$ réis

Três vasos fita carmesim avaliados em $\$ 450$ réis

Duas libras de algodão avaliadas em $\$ 600$ réis. $^{6}$

O côvado de cada tecido variava de acordo com a sua qualidade, se era de uso comum ou luxuoso. Para Vila Rica, na primeira metade do século XVIII, Alexandra Maria Pereira encontrou nas lojas o côvado de lemiste custando de $3 \$ 500$ a $4 \$ 500$ réis, e o de crepe fino por $\$ 500$ réis. As fitas, como Mariana disse possuir, eram feitas de tecido compridos e estreitos, usado para ornar e atar (PEREIRA, 2004, p. 73). Não encontramos referências que remetam ao tecido denominado Braga. Há, porém, a denominação Bragal, que era um "pano grosseiro utilizado na confecção de bragas (calças interiores, largas e curtas)" (COSTA, 2004, p. 140). O que pode ser vinculado ao próprio hábito das africanas de se enrolarem com tecidos ou utilizá-los como turbante (MÓL, 2002, p.182).

Através do que encontramos sobre o vestuário das libertas da vila de Pitangui, podemos dizer que era ele era composto de roupas simples, utilizadas no dia a dia, bem como de trajes feitos de tecidos finos, joias, sapatos e outros adornos. Não observamos a presença de vestidos, o que pode ser justificado pelo alto custo destes e pela legislação que proibia as mulheres negras de utilizá-los, como observou Alcântara Machado (MACHADO, 1980, p. 94). As peças que compuseram os guarda-roupas das libertas da localidade foram, majoritariamente, as saias e as camisas, feitas de várias tecidos, e algumas, como demonstramos, de veludo, seda, gala e outros panos bem avaliados no mercado.

Algumas peças importadas e de alto valor foram deixadas pelas alforriadas de Pitangui como herança às pessoas com as quais tinham afinidade. Rosa Ferreira da Costa, no ano de 1762, declarou as suas últimas vontades em testamento:

Declaro que deixo de esmola a filha de Joana Capim por nome Maria uma saia de seda de ouro. Declaro que deixo de esmola a filha de Manoel Antunes de Oliveira por nome Thariana uma saia de seda preta e um colete de seda verde.

Declaro que deixo de esmola a filha de Antonio de Araujo Velho uma saia de seda verde.

Declaro que deixo de esmola a minha afilhada Francisca da Costa Gomes de Faria os meus brincos de diamantes e seus laços.

Deixo também de esmola a filha mais velha de Maria de Sousa Brandão uma saia riscada.

Declaro que deixo a Clara filha de Maria Pereira preta forra uma saia de riscado azul e 05 oitavas de ouro.

Declaro que deixo de esmola as filhas de Domingos de Sousa Ferreira duas camisas.

Declaro que deixo de esmola a filha mais velha do licenciado Manoel Irmão Lopes uma saia riscada de passarinho e uma camisa de seda de ouro.

Declaro que deixo a Rosa Varela duas camisas das melhores.

Declaro que deixo de esmola a filha de Ignácia por nome de Cora cinco oitavas de ouro e mais uma volta de corais de braço digo mais quatro ou cinco voltas de corais. ${ }^{7}$

Através do que foi descrito por Rosa, percebe-se a variedade e a qualidade dos tecidos e adornos que ela possuiu: saias e colete feitos de seda, camisas nobres, saias riscadas, corais e brincos de diamantes. Ademais, a descrição daqueles a quem deixa os seus bens demonstra o

\footnotetext{
${ }^{6}$ IHP, Fundo CMP, Seção Justiça, Inventário de Mariana Gomes de Araújo - preta forra. 1775. Cx 015/Dc 004.

7 IHP, Fundo CMP, Seção Justiça, testamento de Rosa Ferreira da Costa. 1762. Cx 094/Dc 013; Testamento de Maria Machado Pereira. 1777. Cx 094/Dc 017.
} 
envolvimento de Rosa com indivíduos de diferentes segmentos sociais: livres e libertos.

Como percebemos, o vestuário das libertas, de modo geral, variou entre roupas simples e luxuosas. As simples poderiam ser utilizadas para a realização dos ofícios que desempenhavam e para ficarem em casa. Já as mais pomposas, sugerimos que eram usadas em festas, em cerimônias religiosas e em outras ocasiões que exigiam portarem-se de forma mais requintada.

\section{Os trajes utilizados pelas libertas no momento da morte}

A religião Católica, trazida para a América portuguesa através do processo de colonização, influenciou os costumes, a justiça e a moral dos indivíduos que ali viveram. A partir da Santa Sé, estruturava-se todo o repertório de normas de cunho administrativo e doutrinário determinado a guiar a vida religiosa dos fiéis no Novo Mundo português (CAHON, 2014, p. 85). Foram variadas as formas de manifestação da religião cristã e muitas vezes ela foi reelaborada pelos seus praticantes no além-mar, principalmente por se tratar de um território composto de indivíduos culturalmente diferentes: africanos, europeus e indígenas. Desta forma, o catolicismo na América portuguesa foi marcado pelo sincretismo, sobretudo no que tange à prática dos cultos cristãos pelos africanos e seus descendentes, mesclados com as religiões do continente negro (THORNTON, 2004, p. 319).

Segundo Cláudia Rodrigues, a simbologia das vestes no momento da morte fazia parte tanto da cultura cristã quanto para os africanos. A mortalha garantia a "boa morte" e uma passagem tranquila para o outro mundo (RODRIGUES, 1997, p. 196). Para os cristãos, o objetivo centrava-se em garantir a salvação, e para os africanos era o momento de reencontrar os ancestrais. O local a ser enterrado e a mortalha solicitada tinham o seu ritual e definiam o poder econômico e o prestígio social dos indivíduos.

As mortalhas eram caras e aqueles que não possuíam o valor suficiente para comprá-las eram enterrados apenas envoltos em um lençol. De acordo com a cultura cristã, algumas cores poderiam atrapalhar o desenlace da alma do corpo, outras poderiam auxiliar na entrada no outro plano. As crianças, quando batizadas, eram enterradas com vestes coloridas, simbolizando a pureza e a certeza da salvação. $E$ as mortalhas de santos tinham como finalidade pedir a intercessão e a proteção destes junto a Deus.

João José Reis destaca que a utilização de mortalhas de santos representava um apelo para que eles ajudassem os que as vestiam. O autor observou que em Salvador os homens se vestiam de mortalhas de santos e as mulheres de santas (REIS, 1991, p. 120). Rodrigues verificou os seguintes tipos de mortalhas no Rio de Janeiro: as coloridas, as de santos, os trajes oficiais de militares e sacerdotes, as das agremiações religiosas, as roupas de nobres e as roupas simples (RODRIGUES, 1997).

Algumas mulheres forras da vila de Pitangui destacaram a forma como seriam enterradas: algumas com hábitos de santos com que tinham mais afinidade e outras envoltas em lençóis. As mortalhas mais citadas foram as de Nossa Senhora do Rosário, Nossa Senhora do Monte do Carmo, Nossa Senhora da Conceição e de São Francisco. Quitéria Martins, por exemplo, no ano de 1788, disse que gostaria de ser enterrada da seguinte forma:

Declaro que meu corpo será amortalhado no habito de Nossa Senhora da Conceição e sepultado nesta capela do Onça nas sepulturas da nossa Irmandade e acompanhará meu corpo o pároco ou capelão com mais dois outros sacerdotes, todos estes dirão missa de corpo presente pela minha alma de esmola de uma oitava de ouro. ${ }^{8}$

Percebe-se, através deste pedido, a vontade da liberta ser enterrada no hábito da santa que tinha maior devoção, explicitando, dessa forma, a irmandade a que pertencia: a de Nossa Senhora da Conceição dos Pardos.

Rosa Ferreira da Costa também ressaltou que deveria ser enterrada vestida com uma

${ }^{8}$ IHP, Fundo CMP, Seção Justiça, testamento de Quitéria Martins - preta forra. 1784. Cx 022 Dc 012. 
mortalha. Neste caso, escolheu a de São Francisco e pediu que fosse sepultada na matriz de Nossa Senhora dos Raposos, acompanhada pelo reverendo e demais sacerdotes que estivesse na freguesia, pela Irmandade das Almas e do Santíssimo Sacramento. ${ }^{9}$ Já Ana Abreu, natural de Costa da Mina, em 1779 disse que ao morrer seria amortalhada em hábito de Nossa Senhora do Rosário dos pretos, mesma santa da irmandade de que fazia parte, acompanhada dos sacerdotes que estivessem na vila de Pitangui no momento. ${ }^{10}$

Maria Machado, da mesma forma que Ana Abreu, pediu que as irmandades a acompanhassem após a morte. Descreveu em seu testamento as suas últimas vontades:

Declaro que falecendo será meu corpo amortalhado em um hábito de Nossa Senhora do Monte do Carmo que se mandará fazer e [...] acompanharão meu corpo à sepultura o meu reverendo pároco e três sacerdotes mais os quais todos me darão missa de corpo presente de que se the dará esmola de citação de resto por ela como de acompanhar se lhe dará o que com feito digo o que por direito Ihe competir. Declaro que sou irmã da Irmandade de Nossa Senhora do Rosário desta vila o que acompanhará meu corpo a sepultura e [meus] filhos o farão os anuais que se Ihe deixarem. Lhe deixo mais de esmola oito oitavas de ouro. Declaro que se mandarão dizer vinte e cinco missas pela minha alma de esmola de meia oitava de resto e serão ditas pelos sacerdotes que eleger. Declaro que sou irmã da Santa Casa de Jerusalém Ihe deixo de esmola oito oitavas que meu testamenteiro passará logo os anuais que lhe tiver devendo. ${ }^{11}$

Diferentemente de Rosa, Quitéria e Maria Machado, que desejavam que seus corpos fossem cobertos de forma suntuosa, feitos todos os ritos fornecidos pelas Irmandades e confrarias, Ana Cabral, em seu testamento, disse que seu corpo seria amortalhado apenas em um lençol. ${ }^{12}$ Parte das pessoas que não detinham poder aquisitivo ou que deixavam muitas dívidas a serem pagas no momento da morte, não podiam como arcar com os cerimoniais. Desta forma, optavam pela simplicidade no enterro, evitando mais despesas e gastos para o testamenteiro.

Diante disso, verificamos que os trajes fúnebres variaram de acordo com o que as libertas conseguiram acumular em vida, ou seja, diante da situação econômica em que se encontravam próximas ao falecimento. As que descreveram mais bens nos testamentos e inventários foram as que mais ostentaram nos rituais da morte. As que viveram de forma mais simples, optaram pelo funeral modesto.

\section{Conclusão}

Além de cobrir os corpos, as roupas traziam consigo simbologia e significado. Segundo Cláudia Mól, o trajar estava ligado às várias funções que o indivíduo desempenhava na sociedade e à sua posição dentro de um grupo. A comunidade, desta forma, era espaço de exteriorização das aparências e os trajes atuavam como poderoso demarcador das hierarquias.

As libertas de Pitangui possuíram variadas indumentárias, contendo tanto trajes feitos de panos nobres e de tecidos grosseiros. Os últimos, como observamos, provavelmente eram usados no lar e para realizar seus ofícios. E os primeiros, utilizados mais no ambiente urbano, nos dias de festa, cerimônias religiosas e nas irmandades leigas. Como se tratava de uma sociedade que prezava pelas aparências, vestir-se com tecidos e adornos nobres afirmava o poderio econômico das libertas e o distanciamento das camadas sociais inferiores.

Além das ruas das vilas e dos arraiais serem utilizados como palco de ostentação das aparências, o momento do funeral também era usado para demonstrar o poder econômico dos indivíduos e a influência destes sobre a comunidade em que viviam. Uma parcela das manumitidas tinha condições de arcar com enterros grandiosos, composto com vários padres, irmandades leigas,

\footnotetext{
${ }^{9}$ IHP, Fundo CMP, Seção Justiça, testamento de Rosa Ferreira da Costa - preta forra. 1762. Cx 094 Dc 013.

10 IHP, Fundo CMP, Seção Justiça, testamento de Ana de Abreu - preta forra. 1779. Cx 094 Dc 032.

11 IHP, Fundo CMP, Seção Justiça, testamento de Maria Machado Pereira. 1777. Cx 094/Dc 017.

12 IHP, Fundo CMP, Seção Justiça, testamento de Ana Cabral - preta forra. 1750. Cx 032 Dc 007.
} 
velas, várias missas e hábitos de seus santos de devoção. Outra parcela possuía apenas o suficiente para pagar as dívidas que deixara enquanto viva, pedindo apenas que fosse enterrada em um lençol, da forma mais simples.

À vista disso, concluímos que, para parte das alforriadas, o acesso à liberdade possibilitou significativa acumulação de pecúlio e como fruto disso, elas puderam comprar vestes, joias e adornos bem avaliados. Além de compor as indumentárias, as joias e adornos também podem ser considerados como uma das formas de investimento econômico para este segmento social, pois poderiam facilmente ser trocadas, vendidas ou usadas como crédito. O que denota que estas mulheres não eram desclassificadas socialmente e economicamente, e que se situavam em um grupo intermediário que só crescia na segunda metade do século XVIII e início do XIX. Ademais, podemos notá-las como agentes operantes nas vilas e arraiais, que buscavam se adequar às normas e signos vigentes, e que faziam tratos com pessoas de diversos segmentos sociais, vislumbrando melhores condições de vida e reconhecimento.

\section{Fontes}

\section{Impressa}

SILVA, Antonio Moraes. Diccionario da lingua portugueza - recompilado dos vocabularios impressos ate agora, e nesta segunda edição novamente emendado e muito acrescentado, por ANTONIO DE MORAES SILVA. Lisboa: Typographia Lacerdina, 1813.

\section{Manuscritas}

Arquivo do Instituto Histórico de Pitangui - Fundo: CMP (Câmara Municipal de Pitangui), Seção Justiça.

\section{Inventários}

\begin{tabular}{|l|l|l|l|}
\hline \multicolumn{1}{|c|}{ Inventariado } & \multicolumn{1}{|c|}{ Inventariante } & Ano & Documento \\
\hline Ana de Abreu - preta forra & $\begin{array}{l}\text { Antonio Barbosa Fiuza - preto } \\
\text { forro }\end{array}$ & 1779 & CX 017/003 \\
\hline Ana Cabral - preta forra & Antonio Teixeira & 1750 & CX 032/007 \\
\hline Barbara da Costa- crioula forra & $\begin{array}{l}\text { Manoel Fonseca Rego - pardo } \\
\text { forro }\end{array}$ & 1790 & CX 024/014 \\
\hline $\begin{array}{l}\text { Cipriana Maria da Conceição - } \\
\text { crioula forra }\end{array}$ & Benedito Ferreira - preto forro & 1795 & CX 029/005 \\
\hline $\begin{array}{l}\text { Germana Maria dos Santos - crioula } \\
\text { forra }\end{array}$ & José Aquino Rego & 1799 & CX 034 /011 \\
\hline Jacinta da Rocha - crioula forra & Domingos Pereira Alves & 1768 & CX 012/ 004 \\
\hline Joana Sousa Andrade - crioula forra & Pedro Veloso Carvalho & 1797 & CX 031 /009 \\
\hline Luzia Ferreira Campos - preta forra & Rosa Maria Alves & 1773 & CX 014/002 \\
\hline Maria Benguela - preta forra & N/C & 1799 & CX 034/009 \\
\hline Maria Madalena - crioula forra & Manuel Faria Morato & 1770 & CX 012/015 \\
\hline Mariana Gomes Araujo - crioula forra & Domingos Pinto Coelho & 1775 & CX 015/ 004 \\
\hline $\begin{array}{l}\text { Maurícia Gonçalves Galvão - preta } \\
\text { forra }\end{array}$ & Domingos Alves Oliveira & 1798 & CX 032/007 \\
\hline Rita Maria Sousa - preta forra & Miguel Sousa Soares & 1799 & CX 033/011 \\
\hline Ana Maria Soares - crioula forra & Manoel Joaquim Cordeiro & 1797 & CX 031/010 \\
\hline Leonor Machado - preta forra & N/C & 1796 & CX 031/011 \\
\hline
\end{tabular}




\begin{tabular}{|l|l|l|l|}
\hline \multicolumn{1}{|c|}{ Inventariado } & \multicolumn{1}{|c|}{ Inventariante } & \multicolumn{1}{c|}{ Ano } & \multicolumn{1}{c|}{ Documento } \\
\hline Lourença Veloso - preta forra & N/C & 1781 & CX 019/022 \\
\hline Quitéria Martins - preta forra & Alferes Jose Machado & 1788 & CX 022/012 \\
\hline Bernardo Costa Braga & $\begin{array}{l}\text { Ana Ferreira Rodrigues (preta } \\
\text { forra) }\end{array}$ & 1806 & Cx 043/003 \\
\hline João Silva Carneiro (Preto forro) & Maria Felipe (Preta forra) & 1794 & CX 028/006 \\
\hline Jose Rosa (Preto forro) & Antonia Afonsa (Crioula forra) & 1797 & Cx 031/017 \\
\hline Luciano Manoel Tavares Araujo & Ana Gonçalves (Crioula forra) & 1809 & CX 048/006 \\
\hline
\end{tabular}

Testamentos

\begin{tabular}{|l|l|l|l|}
\hline \multicolumn{1}{|c|}{ Testador } & \multicolumn{1}{|c|}{ Testamenteiro } & Ano & Documento \\
\hline Ana Abreu (preta forra) & Antonio Barbosa Fiuza (preto forro) & 1779 & CX 094/032 \\
\hline $\begin{array}{l}\text { Bárbara da Costa (crioula } \\
\text { forra) }\end{array}$ & Francisco Moutinho (pardo forro) & 1790 & CX 094/057 \\
\hline $\begin{array}{l}\text { Joana Ferreira Souto } \\
\text { (crioula forra) }\end{array}$ & Maria Rosa & 1815 & CX 096/002 \\
\hline $\begin{array}{l}\text { Maria Machado Pereira } \\
\text { (preta forra) }\end{array}$ & Gil Machado (preto forro) & 1777 & CX 094/017 \\
\hline $\begin{array}{l}\text { Rosa Ferreira da Costa } \\
\text { (preta forra) }\end{array}$ & Alferes Jose Ribeiro Domingues & 1762 & CX 094/013 \\
\hline $\begin{array}{l}\text { Joao da Silva Carneiro } \\
\text { (Preto forro) }\end{array}$ & Maria Felipa de Andrade (crioula forra) & 1792 & CX 094/064 \\
\hline \begin{tabular}{l} 
Rosa Rocha (negra forra) \\
\hline João Henrique Lopes
\end{tabular} & Faustina Claudina Silva & 1820 & $\mathrm{CX} 095 / 090$ \\
\hline Ana Cabral & $\begin{array}{l}\text { Rosa Ferreira Silva (preta forra) } \\
\text { Felipa Bal de Sa }\end{array}$ & 1783 & $\mathrm{CX} 094 / 038$ \\
\hline Quitérias Martins & Antonio Ferreira da Costa & 1750 & $\mathrm{CX} 032 / 007$ \\
\hline
\end{tabular}

Testamentárias

\begin{tabular}{|l|l|c|c|}
\hline \multicolumn{1}{|c|}{ Autor } & \multicolumn{1}{|c|}{ Testador } & Ano & Documento \\
\hline $\begin{array}{l}\text { Promotor do } \\
\text { juízo }\end{array}$ & Testamenteiro de Magdalena de Oliveira- preta forra & 1766 & CX 170/005 \\
\hline $\begin{array}{l}\text { Doutor } \\
\text { Promotor }\end{array}$ & $\begin{array}{l}\text { Rosa Ferreira da Silva - crioula forra testamenteira de } \\
\text { João Henrique Lopes }\end{array}$ & 1793 & CX 172/019 \\
\hline
\end{tabular}

\section{Referências}

ALMEIDA, Carla Maria Carvalho de. Hierarquia Social polarizada. Homens ricos, homens bons: produção e hierarquização social em Minas Gerais, 1750-1822. Niterói, 2001. Tese (Doutorado em História). Universidade Federal Fluminense, 2001.

CHAHON, Sérgio. Visões da religiosidade católica no Brasil colonial. Revista Digital Simonsen, Rio de Janeiro, v. 1, n. 1, p. 85-99, 2014.

CARRARA, Angelo Alves. "A Capitania de Minas Gerais (1674-1835): modelo de interpretação de uma sociedade agrária”. História Econômica \& História de Empresas. São Paulo Brasil, v. 3, n. 2, p. 47-63, 2001. 
CASTRO, Hebe. "História Social". In: CARDOSO, Ciro Flamarion; VAINFAS, Ronaldo (orgs). Domínios da história: ensaios de teoria e metodologia. Rio de Janeiro: Campus, 1997, p. 76-96.

COSTA, Manuela Pinto da. "Glossário de termos têxteis e afins". Revista da Faculdade de Letras, Ciências técnicas e do patrimônio. Porto, 2004 I Série vol. III.

DEBRET, Jean Baptiste. Viagem pitoresca e histórica ao Brasil. Tradução de Sérgio Milliet. Belo Horizonte: Ed. Itatiaia Limitada/São Paulo: Ed. da Universidade de São Paulo, 1978.

FIGUEIREDO, Luciano Raposo. O avesso da Memória. Cotidiano e trabalho da mulher em Minas Gerais no século XVIII. Rio de Janeiro: José Olympio, 1999.

FRAGOSO, João; GUEDES, Roberto; SAMPAIO, Antonio Carlos Jucá de (orgs.) Arquivos paroquiais e história social na América Lusa, séculos XVII e XVIII: métodos e técnicas de pesquisa na reinvenção de um corpus documental. Rio de Janeiro: Mauad X, 2014.

GUEDES, Roberto. Dinâmica Imperial no Antigo Regime Português: escravidão, governos, fronteiras, poderes e legados - séc. XVII-XIX. Rio de Janeiro: Mauad X, 2011.

KANTOR, Iris. Tirania da etiqueta nas Minas Gerais Setecentista. LPH: Revista de História. Mariana: Dep. De História/UFOP, Ouro Preto, v. 5, p. 122-137, 1995.

LARA, Silvia Hunold. Fragmentos Setecentistas: escravidão, cultura e poder na América portuguesa. São Paulo: Companhia das Letras, 2007.

LIPOVETSKY, Gilles. O Império do Efêmero: a moda e seu destino nas sociedades modernas. São Paulo: Companhia das Letras, 1989.

MACHADO, Alcântara. Vida e morte do bandeirante. Editora Itatiaia, 1980.

MAGALHÃES, Beatriz Ricardina de. A Demanda do Trivial: vestuário, alimentação e habitação. Revista Brasileira de Estudos Políticos. Belo Horizonte/UFMG, n. 65, p. 153-199, jul. 1997.

MAGALHÃES, Cristiane Maria. Escravos e libertos: homens de ocupações no século XIX. Revista O Olho da História, n. 10, p. 44-52, abr. 2008.

MÓL, Cláudia Cristina. Mulheres forras: cotidiano e cultura - Material em Vila Rica (1750-1800). Mariana, 2002. Dissertação (Mestrado). Universidade Federal de Minas Gerais, 2002.

MÓL, Cláudia Cristina. Entre sedas e baetas: o vestuário das mulheres alforriadas de Vila Rica. Varia História (UFMG. Impresso), v. 32, p. 176-189, 2004.

PAIVA, Eduardo França. Escravidão e Universo Cultural na Colônia: Minas Gerais, 1716-1789. Belo Horizonte: UFMG, 2001.

PEREIRA, Alexandra Maria. Um mercador de Vila Rica: atividade mercantil na sociedade do ouro (1737-1738). Juiz de Fora-MG, 2008. Dissertação (Mestrado em História). Universidade Federal de Juiz de Fora, Programa de Pós-Graduação em História, 2008.

PRIMO, Bárbara Deslandes. Representação e poder simbólico nas joias afrobrasileiras: sobrevivências culturais e ascensão econômica de mulheres forras em São João del Rei no século XVIII. Anais Do II Encontro Internacional De História Colonial. Mneme - Revista de Humanidades. UFRN. Caicó (RN), v. 9. n. 24, p. 1-18, set/out. 2008.

REIS, João José. A morte é uma festa: ritos fúnebres e revolta popular no século XIX. São Paulo: Companhia das Letras, 1991.

ROCHE, Daniel. A Cultura das Aparências: uma história da indumentária (séculos XVII - XVIII). São 
Paulo: SENAC, 2007.

RODRIGUES, Cláudia. Lugares dos mortos na cidade dos vivos: tradições e transformações fúnebres no Rio de Janeiro. Rio de Janeiro: Secretaria Municipal de Cultura, Departamento Geral de Documentação e Informação Cultural, Divisão de Editoração, 1997.

SILVA, Marcus Flávio da. Subsistência e Poder: A política do abastecimento alimentar nas Minas setecentistas. Belo Horizonte, Editora UFMG, 2008.

SOARES, Márcio. "A promessa da alforria e os alicerces da escravidão na América Latina". In: GUEDES, Roberto. Dinâmica Imperial no Antigo Regime Português: escravidão, governos, fronteiras, poderes e legados - séc. XVII-XIX. Rio de Janeiro: Mauad X, 2011, p. 35-50.

THORNTON, John. A África e os Africanos na Formação do Mundo Atlântico 1400-1800. Tradução Marisa Rocha Motta. São Paulo: Campus, 2004.

\section{Nota de autoria}

Ana Caroline Carvalho Miranda é Doutoranda em História pela Universidade Federal de Juiz de Fora, Mestra e Graduada em História pela Universidade Federal de Ouro Preto. É Membro do Laboratório de História Econômica e Social (UFJF), e do Grupo de Pesquisa Escravismo atlântico: família, riqueza e cultura (UFMG). Também é professora nas redes de ensino privada e pública no Estado de Minas Gerais. Pesquisa, atualmente, os seguintes temas: os libertos e o acesso à justiça cível; História da Justiça; Escravidão Atlântica e Antigo Regime Português. E-mail: anacarolinec625@gmail.com.

Como citar esse artigo de acordo com as normas da revista

MIRANDA, Ana Caroline Carvalho. A modéstia e a ostentação no vestuário das mulheres alforriadas na Vila de Pitangui (1750-1820). Sæculum - Revista de História, v. 25, n. 43, p. 180-194, 2020.

\section{Contribuição de autoria \\ Não se aplica}

\section{Financiamento}

O presente trabalho foi realizado com apoio da Coordenação de Aperfeiçoamento de Pessoal de Nível Superior - Brasil (CAPES) - Código de Financiamento 001.

\section{Consentimento de uso de imagem}

Não se aplica

\section{Aprovação de comitê de ética em pesquisa}

Não se aplica

\section{Licença de uso}

Este artigo está licenciado sob a Licença Creative Commons CC-BY. Com essa licença você pode compartilhar, adaptar, criar para qualquer fim, desde que atribua a autoria da obra.

\section{Histórico}

Recebido em 20/05/2020.

Modificações solicitadas em 24/08/20.

Aprovado em 31/08/2020. 